\title{
Book Review \\ Book Review: Devolution and Localism in England. By David M. Smith and Enid Wistrich. Farnham: Ashgate, 2014, 122 pp.; ISBN: 978-1-14724-3079-3.
}

\author{
$\varnothing$ ivind Bratberg \\ Department of Political Science, University of Oslo, 0316 Oslo, Norway; E-Mail: oivind.bratberg@stv.uio.no
}

Submitted: 20 November 2014 | Accepted: 25 November 2014 | Published: 15 December 2014

\begin{abstract}
Book Review: Devolution and Localism in England. By David M. Smith and Enid Wistrich. Farnham: Ashgate, 2014,122 pp.; ISBN: 978-1-14724-3079-3.
\end{abstract}

\section{Keywords}

Britain; governance; local politics; regionalization

Issue

This book review is part of a regular issue of Politics and Governance, edited by Professor Andrej J. Zwitter (University of Groningen, The Netherlands) and Professor Amelia Hadfield (Canterbury Christ Church University, UK).

(C) 2014 by the author; licensee Cogitatio (Lisbon, Portugal). This article is licensed under a Creative Commons Attribution 4.0 International License (CC BY).

The territorial structures of the UK have been the source of a wide and growing literature over the decade and a half since the Scottish Parliament and the Welsh Assembly were created. Its strands have been diverse. Some contributions have considered the constitutional implications for London, others have dealt specifically with the emerging politics in Scotland and Wales while yet another strand has addressed British devolution against a wider European backdrop. Here, Spain, Belgium and to a lesser extent Italy have been important comparative cases of regionalisation.

Considered against the backdrop of this literature, Devolution and Localism in England, develops its own frontier in dealing specifically with developments in England. The focus is a timely one, since there is an ongoing debate on the "English question" following the Scottish independence referendum and the preceding vow from the three dominant UK party leaders to devolve more powers to the Scots. Professors Smith and Wistrich also wish to go beyond the discussion about England's role within the UK to look at sub-state structures more broadly - that is, the broader set of territorial structures that have come and gone since the mid1990s at the local, city and regional level.
In England, the prelude for territorial reforms after 1997 was a patchwork of different territorial denominations used by public administration. Amazingly for a modern state of its size, Britain has not been supplied with any uniform regional structures. Civil servants, whether dealing with energy supply, infrastructure or food security have conventionally had a patchwork of unofficial regional entities to relate to. John Major's Conservative government made the first step to unify the patchwork in creating the Government Offices for the Regions in 1994, establishing nine English regions (adding to existing offices in Scotland, Wales and Northern Ireland) and co-locating the regional outposts of various government agencies. These regions would also be the entities for EU funding of regional development, a crucial driving factor in the urge towards a regional level of administration in England.

The Labour Party's plan when entering government in 1997 was to expand on and democratise these structures. The leap towards regionalism joined together several of its overarching ambitions. English regions would enhance the coordinating capacity of central government and strengthen democratic accountability. Moreover (and highly significant in light of later devel- 
opments), a regional structure for England was seen as an appropriate response to the creation of a Scottish Parliament and a Welsh Assembly, without treating the English colossus as a whole. The creation of Regional Development Agencies was symptomatic of the late1990s pursuit of "joined-up government". Here was a tying together of business, local government and civil society, all under the tutelage of the Department of Business, Innovation and Skills and with strategic funding from London. The democratic element would be added through the creation of Regional Assemblies, initially based on indirect election from local authorities.

A few years later, the government's attempt at making Regional Assemblies directly electable was abruptly halted by the resounding rejection at the first referendum held over the issue, in the North East in 2004. Thereafter, the ambition of elected Assemblies was quietly put to rest, the Assemblies themselves then dismantled under Gordon Brown's government. Instead, the appointed Regional Development Agencies were given an injection of democratic accountability through regional ministers and regional select committees in the House of Commons. To conclude the saga, with the change of government in 2010 , all these structures were put to a grinding halt and replaced by a set of voluntary arrangements, among them the so-called local enterprise partnerships that unite local authorities and businesses. Meanwhile, a wide range of substate structures are on the table in what has historically been one of Europe's most centralised polities. Elected mayors? City regions? Or another version of elected assemblies at the regional level? If so, what powers will be vested in them, and how will they relate to the levels above and below?

These topics are all addressed by Smith and Wistrich's volume, which thus starts from a promising point of departure. Given the richness of the British experience and its amenability to relevant public administration theory, it is however arguable that the topic at hand should have been better exploited. There are three basic criticism to be raised here: one substantial, one theoretical and one methodological.

Substantially, it is never clear how the analysis of the book holds together-beyond the evident observation that England is served by a heavily inconsistent structure of territorial government and that it is impossible to agree on a model that serves all the desired purposes. Devolution and Localism in England manages to give a fairly encompassing picture of the thorny process of territorial reform, but without a cure, let alone a precise diagnosis, to the current predicament. On page 26, it paraphrases from interviews with regional elites about the post-1997 structures for England: "Although most are critical in detail of the then-existing regional institutional set-up...there was near unanimous agreement that there was a necessity for a regional level when it came to strategic planning". This exempli- fies a trap that the book too often walks into: general questions are asked about what political decisionmakers want to accomplish, only to observe that these goals are not accomplished. Where the politicians have failed to grasp the dynamic set in train, the authors retell the dilemmas rather than addressing the "whys" and the "wheretos".

This problem could have been overcome or at least mitigated by a clear engagement with relevant theoretical schools of thought. Smith and Wistrich list a number of concepts and theories, but rarely go in depth. Thereby they also fall short of putting the English conundrum into perspective or pinpointing its shortcomings in a language that can travel beyond the British Isles. The multi-level governance literature is intended not only to describe but also to compare, explain and assess changes in territorial government. Arend Lijphart's ideal types of "consensus" and "Westminster" models of democracy are but one conceptualisation of fundamentally different organisation of democracies and how they tend to cluster. And institutional theory could have enlightened the analysis of how established institutions generate a path dependence of ideas and vested interests which may lead to stagnation and frustration for ambitious reformers.

By leaning upon any of these schools of thought, the analysis could have been more refined and also reached a wider audience. Notably, this is not a call for scholarly abstraction to replace an analysis close to developments on the ground. Rather, it is a call for stringency in order to distinguish crossroads on the muddy trajectory of repeated and confused territorial reforms that has characterised Britain post-1997.

Methodologically, the book would have benefitted from a more transparent and stringent use of data. Smith and Wistrich draw on an admirable multitude of sources, yet when and how they feed into the analysis is not always clear. According to the preface, the authors "make use of library research, policy analysis and our own empirical material", the latter consisting of a large set of interviews with regional elites from the political parties, business and civil society. Findings from the interviews reach the surface on numerous occasions, but without it being entirely clear why and with what authority they speak.

Despite these perceived shortcomings, Devolution and Localism in England has a lot to offer. It takes the reader through parallel, complex processes unfolding since 1997 and presents some of the key dilemmas. And empirically, we get to hear a selection of voices from the regional level, precisely those stakeholders that have been closest to the processes on the ground, having seen structures be raised and vanish, just as they have learned to make the best of them.

The future of territorial government in Britain is uncertain, and much of the uncertainty relates to the big constitutional questions, such as whether Scotland will 
remain, whether Wales should be considered on par with the Scots within the Union, and whether there should be English votes for English laws to compensate for the absence of English devolution. Beyond these wider issues are the intra-English ones, related to democratic accountability and revitalisation of civil society. Moreover, aspirations to change the balance of the British economy, enhance social mobility etc. are also typically related to the argument that structures of territorial government must change. Towards all these noble aims, territorial structures will play an essential role. But as Smith and Wistrich point out, there is little reason for immediate optimism. In a short but succinct chapter 7 they sum up the findings and point towards likely developments for the future. "While central government talk is of empowering and permissive decen- tralisation, it is unclear what this could mean in practice", the authors note (p. 107) and observe that even the concept of "region" has now been attached to so different territorial entities as to be rendered if not meaningless, then at least inadequate. While the Labour Party is guilty of excessive top-downisn in its pursuit of reforms, the Coalition government is so geared towards competition that other concerns (such as a consistent structure) may be neglected or opposed. The British building site is likely to remain an interesting venue for researchers on territorial reform for some time.

\section{Conflict of Interests}

The author declares no conflict of interests.

\section{About the Author}

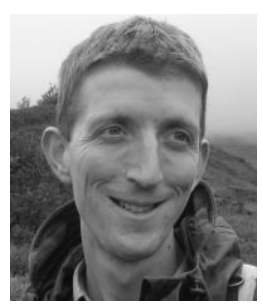

\section{Dr. Øivind Bratberg}

Øivind Bratberg is a post-doctoral researcher at the Department of Political Science, University of Oslo. He completed his PhD in Oslo in 2011. His dissertation addressed how devolution to Scotland and Wales has affected the territorial structures of the three statewide parties in Britain. Among other research interests, Bratberg is co-author of The Nordic Model of Social Democracy (Palgrave, 2013) and a textbook on research methods in textual analysis. 